\title{
Strategy for Rapid Recovery of Simultaneous Sulfide and Nitrite Removal under High Substrate Inhibition
}

\section{Kaiquan Wang}

Zhejiang Gongshang University

\section{Mahmood Qaisar}

COMSATS University Islamabad

\section{Bilong Chen}

Zhejiang Gongshang University

Siyi Liu

Zhejiang Gongshang University

\section{Yuanyuan Wu}

Zhejiang Gongshang University

\section{Ziling Zheng}

Zhejiang Gongshang University

Jing Cai ( $\sim$ caijing@zju.edu.cn )

Zhejiang Gongshang University

\section{Research Article}

Keywords: Simultaneous sulfide and nitrite removal process, Recovery strategy, Inhibition, Reducing influent substrate concentration, Regulating influent $\mathrm{pH}$

Posted Date: August 24th, 2021

DOI: https://doi.org/10.21203/rs.3.rs-597012/v1

License: (c) (i) This work is licensed under a Creative Commons Attribution 4.0 International License. Read Full License

Version of Record: A version of this preprint was published at Biochemical Engineering Journal on February 1st, 2022. See the published version at https://doi.org/10.1016/j.bej.2022.108368. 


\section{Abstract}

The paper deals with the strategy for a quick recovery of reactor treating sulfide and nitrite simultaneously under inhibition caused by high substrate concentration. For influent sulfide concentration of $360 \mathrm{mg} \mathrm{S} / \mathrm{L}$, respective sulfide and nitrite removal percentages dropped to $74.19 \%$ and $14.33 \%$ due to inhibition caused by high sulfide and nitrite concentrations. It was found that reduction in the influent substrate concentration ( $300 \mathrm{mg} \mathrm{S} / \mathrm{L}$ ) could not revive the nitrite removal performance in 4 days' operation, which still showed a declining tendency from $47.16-18.52 \%$. Regulating the influent $\mathrm{pH}$ around $6.70 \pm 0.10$, it only took 4 days to recover the performance for $300 \mathrm{mg} \mathrm{S} / \mathrm{L}$. Furthermore, at influent sulfide concentration increased to $360 \mathrm{mg} \mathrm{S} / \mathrm{L}$, respective sulfide and nitrite removal percentages were $99.76 \pm 0.27 \%$ and $100 \%$. The strategy of regulating influent $\mathrm{pH}$ could recover the process performance in a short term, which would provide great convenience for subsequent process research.

\section{Introduction}

Pulp production, pharmaceuticals, and oil refining industries generate large amounts of sulfur and nitrogen-containing wastewater (Show et al. 2013). Simultaneous sulfide and nitrite removal process is well-established autotrophic biological denitrification process, which can achieve sulfide and nitrite removal at the same time, and recovers elemental sulfur from wastewater, so this novel process has broad application prospects (Mahmood et al. 2007). High influent substrate concentration would pose an inhibitory effect on the process performance (Yuan et al. 2020). The process performance would be greatly deteriorated upon introduction of substrate concentration at certain level (Zhang et al. 2019), and even reach on the verge of irreversible collapse. Furthermore, sulfide and nitrite are both toxic to the microbial communities of the process, and have a serious inhibitory effect on the metabolic pathways (Xu et al. 2019; Zhou et al. 2007), which are prone to the performance deterioration.

However, little has been investigated about the recovery of the process performance once inhibited by high influent substrate. Generally, reducing the influent substrate concentration is an effective strategy to solve the problem, sometimes it takes a long time to be restrained by the strategy (Zheng et al. 2013). In case of failure to restore the process performance by reducing the influent substrate concentration failed to take effect on mitigate the deterioration of the performance, what strategy should be adopted? The objective of the present study was to answer the above-mentioned question. The sulfide and nitrite removal performance of was investigated at various sulfide concentrations (60-360 mg S/L), and the nature of products was investigated. After the process inhibition due to high influent sulfide concentration, two strategy were applied to recover the performance, which included the reduction of the influent substrate concentration and regulation of the influent $\mathrm{pH}$. Based on the Principal Component Analysis (PCA) and multiple comparisons, the effectiveness of regulating the influent $\mathrm{pH}$ for the rapid performance recovery was validated.

\section{Materials And Methods}




\subsection{Inoculum, reactor and synthetic wastewater}

The inoculum was collected from the anaerobic reactor working at Municipal Wastewater Treatment Plant (WWTP) in Hangzhou city. Its volatile suspended solids (VSS) were $6.09 \mathrm{~g} / \mathrm{L}$.

A laboratory-scale EGSB reactor was operated during the experiment, which was made of perspex with an effective volume of $6 \mathrm{~L}$. A peristaltic pump was used to inject the synthetic wastewater, and the other pump was used to control the reflux ratio of 1:2. The hydraulic retention time (HRT) was fixed at 13.33h, while the temperature was controlled at $25 \pm 2^{\circ} \mathrm{C}$.

The synthetic wastewater contained $\mathrm{Na}_{2} \mathrm{~S} \cdot 9 \mathrm{H}_{2} \mathrm{O}, \mathrm{NaNO}_{2}, \mathrm{NaHCO}_{3}(1 \mathrm{~g} / \mathrm{L}), \mathrm{MgCl}_{2}(0.765 \mathrm{~g} / \mathrm{L})$, $\mathrm{KH}_{2} \mathrm{PO}_{4}(0.765 \mathrm{~g} / \mathrm{L}),\left(\mathrm{NH}_{4}\right)_{2} \mathrm{SO}_{4}(0.24 \mathrm{~g} / \mathrm{L})$ and trace element solution $(1 \mathrm{~mL} / \mathrm{L})$. The trace element solution was formulated according to Mahmood et al.(Mahmood et al. 2007). The nitrite concentrations were fed according to a sulfide to nitrite molar ratio (3:2). The influent $\mathrm{pH}$ was maintained around $7.0 \pm 0.1$, which was adjusted by $0.1 \mathrm{M} \mathrm{HCl}$ solution.

\subsection{Experimental procedure}

The operation of the reactor was divided into three stages, which lasted for $62 \mathrm{~d}$. Table 1 enlists the detailed operating conditions of the bioreactor during different stages. In Stage I, the influent sulfide concentration was increased from $60 \mathrm{mg} \mathrm{S} / \mathrm{L}$ to $360 \mathrm{mg} \mathrm{S} / \mathrm{L}$ with a gradient of $60 \mathrm{mg} \mathrm{S} / \mathrm{L}$. At influent sulfide concentration of $360 \mathrm{mg} / \mathrm{L}$, the simultaneous sulfide and nitrite removal performance process was inhibited due to lower sulfide and nitrite removal percentages. During Stage II, decreasing the influent substrate concentration (300 mg S/L) was tried to recover the performance of the reactor; however, it did not work on short term basis. Finally, decreasing the influent $\mathrm{pH}(6.70 \pm 0.10)$ was applied to recover the reactor performance, and the influent sulfide concentration was increased to $360 \mathrm{mg} \mathrm{S} / \mathrm{L}$. 
Table 1

Operating conditions of the bioreactor at different stages

\begin{tabular}{|c|c|c|c|c|c|c|c|c|c|}
\hline Stage & प & & & & & & प & प & \\
\hline Time(d) & $1-8$ & $9-16$ & $\begin{array}{l}17- \\
24\end{array}$ & $\begin{array}{l}25- \\
31\end{array}$ & $32-38$ & $39-45$ & $46-49$ & $50-57$ & $58-62$ \\
\hline $\mathrm{HRT}(\mathrm{h})$ & 13.33 & & & & & & & & \\
\hline $\begin{array}{l}\mathrm{S} / \mathrm{N} \text { molar } \\
\text { ratio }\end{array}$ & $3: 2$ & & & & & & & & \\
\hline Inf. pH & $7.00 \pm$ & .10 & & & & & $\begin{array}{l}7.00 \pm \\
0.10\end{array}$ & $6.70 \pm 0.1$ & \\
\hline $\begin{array}{l}\text { Inf. sulfide } \\
\text { (mg S/L) }\end{array}$ & 60 & 120 & 180 & 240 & 300 & 360 & 300 & 300 & 360 \\
\hline $\begin{array}{l}\text { Inf. nitrite } \\
\text { (mg N/L) }\end{array}$ & 23.33 & 46.66 & 70.00 & 93.33 & 116.67 & 140.00 & 116.67 & 116.67 & 140.00 \\
\hline
\end{tabular}

\subsection{Analytical procedures}

The influent and effluent $\mathrm{pH}$, nitrate-nitrogen, nitrite-nitrogen, ammonia-nitrogen and sulfide-sulfur were analyzed according to standard methods(APHA et al. 1998). An ion chromatograph (DIONEX-900) analyzed thiosulfate-sulfur, sulfite-sulfur and sulfate-sulfur concentration after passing through a 0.45 $\mu \mathrm{m}$ filter. The elemental sulfur and nitrogen gas were estimated according to principle of mass conservation, which were calculated as Eq. (1) and Eq. (2).

$\left[\mathrm{S}_{0}\right]=\left[\mathrm{HS}^{-}\right]_{\mathrm{inf}}\left[\mathrm{HS}^{-}\right]_{\mathrm{eff}}-\left[\mathrm{SO}_{4}{ }^{2-}\right]_{\mathrm{eff}}\left[\mathrm{S}_{2} \mathrm{O}_{3}{ }^{2-}\right]_{\mathrm{eff}}(1)$

$\left[\mathrm{N}_{2}\right]=\left[\mathrm{NO}_{2}^{-}\right]_{\mathrm{inf}}\left[\mathrm{NO}_{2}^{-}\right]_{\mathrm{eff}}-\left[\mathrm{NO}_{3}{ }^{-}\right]_{\mathrm{eff}}+\left[\mathrm{NH}_{4}{ }^{+}\right]_{\text {Consmp }}(2)$

Where: $\left[\mathrm{S}_{0}\right]$ and $\left[\mathrm{N}_{2}\right]$ were elemental sulfur and nitrogen gas produced in the reactor; $\left[\mathrm{HS}^{-}\right]_{\mathrm{inf}}$ and $\left[\mathrm{NO}_{2}{ }^{-}\right]_{\text {inf }}$ were the influent concentration of corresponding substances, respectively $(\mathrm{mg} / \mathrm{L}) ;\left[\mathrm{HS}^{-}\right]_{\mathrm{eff}}\left[\mathrm{SO}_{4}{ }^{2-}\right]_{\mathrm{eff}}$, $\left[\mathrm{S}_{2} \mathrm{O}_{3}{ }^{2-}\right]_{\mathrm{eff}}\left[\mathrm{NO}_{2}{ }^{-}\right]_{\mathrm{eff}}$ and $\left[\mathrm{NO}_{3}{ }^{-}\right]_{\text {eff }}$ were the effluent concentration of corresponding substances $(\mathrm{mg} / \mathrm{L})$; $\left[\mathrm{NH}_{4}{ }^{+}\right]_{\text {Consmp }}$ was the concentration of consumed ammonium, which was the derivative of the influent and effluent concentrations.

Multiple comparisons were made using SPSS 26.0 based on non-parametric tests. The statistical significance was estimated via Mann-Whitney $U$ test at 0.05 level of significance. Principal Component Analysis (PCA) was also performed by SPSSAU v20.0.

\section{Results And Discussion}




\subsection{Operation performance by elevating influent substrate concentration}

Figure 1-3 showed the performance of simultaneous sulfide and nitrite removal process. When the influent sulfide concentration was gradually increased from $60 \mathrm{mg} \mathrm{S} / \mathrm{L}$ to $300 \mathrm{mg} \mathrm{S} / \mathrm{L}$ (Stage I), the respective sulfide and nitrite removal percentages were $92.65 \pm 5.94 \%$ and $99.91 \pm 0.30 \%$ (Fig. 2 and Fig. 3), with the influent pH controlled at $7.0 \pm 0.1$ (Fig. 1).

It was observed that there was a slope between influent concentration of $60-180 \mathrm{mg} \mathrm{S} / \mathrm{L}$ (low concentration) and $240-300 \mathrm{mg} \mathrm{S} / \mathrm{L}$ (high concentration). When the influent sulfide concentration was in the range of $60-180 \mathrm{mg} \mathrm{S} / \mathrm{L}$, the effluent $\mathrm{pH}$ showed a slight increasing trend $0.26-0.65(\Delta \mathrm{pH})$. With the influent sulfide concentration in the range of $240-300 \mathrm{mg} \mathrm{S} / \mathrm{L}$, the effluent $\mathrm{pH}$ greatly went up with an increase of 1.52-2.11. This phenomenon was coincided with the variation of final products of the process. Sulfate $(63.27 \pm 12.24 \%$ accounted for oxidized sulfide) and nitrogen gas (101.61 $\pm 20.09 \%$ accounted for reduced nitrate) were the main product of the influent sulfide concentration of $60-180 \mathrm{mg}$ S/L. However, the elemental sulfur (61.76 $\pm 3.53 \%$ accounted for oxidized sulfide) and nitrogen gas (121.90 $\pm 7.50 \%$ accounted for reduced nitrite) were the main product at high sulfide concentration of 240-300 mg S/L. When sulfide was oxidized to element sulfur, it consumed $1 \mathrm{~mol} \mathrm{OH}^{-}$per mol sulfide (Eq. 3); when it was oxidized to sulfate, it consumed $9 \mathrm{~mol} \mathrm{OH}^{-}$per mol sulfide (Eq. 4). Hence, the variations of effluent $\mathrm{pH}$ between $60-180 \mathrm{mg} \mathrm{S} / \mathrm{L}$ and $240-300 \mathrm{mg} \mathrm{S} / \mathrm{L}$ were caused by the types of final product.

$\mathrm{HS}^{-}+\mathrm{OH}^{-} \rightarrow \mathrm{S}_{0}+\mathrm{H}_{2} \mathrm{O}+2 \mathrm{e}^{-}$

$\mathrm{HS}^{-}+9 \mathrm{OH}^{-} \rightarrow \mathrm{SO}_{4}{ }^{2-}+5 \mathrm{H}_{2} \mathrm{O}+8 \mathrm{e}^{-}$

Furthermore, the ammonium consumption was significant at high influent concentration, which was $18.71 \pm 2.96 \mathrm{mg} \mathrm{N} / \mathrm{L}$ at $240 \mathrm{mg} \mathrm{S} / \mathrm{L}$, and $32.42 \pm 4.88 \mathrm{mg} \mathrm{N} / \mathrm{L}$ at $300 \mathrm{mg} \mathrm{S} / \mathrm{L}$. To date, it is well established that the sulfide-driven autotrophic denitrification was coupled with anaerobic ammonium oxidation (Anammox) (Deng et al. 2021), which was consistent with our experiment.

When the influent sulfide concentration was increased to $360 \mathrm{mg} \mathrm{S} / \mathrm{L}$ (Stage I), there was a sudden reduction in the sulfide and nitrite removal performance, and the sulfide removal percentage decreased from $88.25-74.19 \%$, while that of nitrite dropped from $42.58-14.33 \%$. In the end, there were $93.66 \mathrm{mg}$ $\mathrm{S} / \mathrm{L}$ residual sulfide and $103.16 \mathrm{mg} \mathrm{N} / \mathrm{L}$ residual nitrite in the effluent. According to literature, sulfide inhibited denitrification at the concentrations higher than $200 \mathrm{mg} \mathrm{S} / \mathrm{L}$ (An et al. 2010). Cardoso et al. found that sulfide exerted an inhibitory effect on denitrification by approximately 21 -folds, when its concentration increased from $80 \mathrm{mg} \mathrm{S} / \mathrm{L}$ to $320 \mathrm{mg} \mathrm{S} / \mathrm{L}$ (Cardoso et al. 2006). As previously mentioned, the process would be inhibited by 36-60 mg N/L nitrite, and a 50\% inhibition was also found above 48 $\mathrm{mg} \mathrm{N} / \mathrm{L}$ (Fajardo et al. 2014). It suggested that the collapse of removal performance was induced by inhibition caused by sulfide and nitrite at high influent substrate concentration. 


\subsection{Rapid recovery strategy for high substrate inhibition}

In order to recover the performance of the bioreactor, the strategy of reducing influent substrate concentration (Stage II) was primarily used. In 4 days' operation, sulfide removal percentage quickly recovered to $91.21 \pm 1.78 \%$, however, nitrite removal percentage still showed a declining tendency, which descended from $47.16-18.52 \%$. The results showed that reducing the influent substrate failed to recover the nitrite removal performance on a short-term basis (4 days). During a severe nitrite inhibition (its concentration was higher than inhibition parameter), Tang et al. also found that nitrite removal performance was hard to be recovered by decreasing substrate concentration, only achieved $89 \%$ after 39 days, which was due to high inhibition effect of nitrite (Tang et al. 2010).

Many studies have shown that $\mathrm{pH}$ has a significant effect on the denitrification process (Karanasios et al. 2010). PCA was used to analyze the relation of $\Delta \mathrm{pH}$ and products of the stage I (60-300 mg S/L). Two principal components were extracted, and the equations related to principal components and $\Delta \mathrm{pH}$ were established (Eqs. 3-5), which suggested an excellent linear relationship between the concentrations of products and $\Delta \mathrm{pH}$ (Fig.S1, $\left.R^{2}=0.9790\right)$. It was supposed that the performance of the bioreactor at 360 $\mathrm{mg} \mathrm{S} / \mathrm{L}$ was as good as that at $300 \mathrm{mg} \mathrm{S} / \mathrm{L}, \Delta \mathrm{pH}$ was as high as 2.41 according to Eq. (3), which meant that the effluent $\mathrm{pH}$ of $360 \mathrm{mg} \mathrm{S} / \mathrm{L}$ reached 9.41 , much higher than inhibited $\mathrm{pH}$ of 9.0 for denitrification (Chung et al. 2014; Fajardo et al. 2014).

$\Delta \mathrm{pH}=0.02008 \times \mathrm{PCA} 1-0.00322 \times \mathrm{PCA} 2(3)$

PCA $1=-0.152 \times[\mathrm{HS}]_{\mathrm{eff}} 0.014 \times\left[\mathrm{SO}_{4}{ }^{2-}\right]_{\mathrm{eff}}+0.149 \times\left[\mathrm{S}_{2} \mathrm{O}_{3}{ }^{2-}\right]_{\mathrm{eff}}+0.152 \times\left[\mathrm{S}_{0}\right]-0.150 \times\left[\mathrm{NO}_{2}{ }^{-}\right]_{\text {eff }}+0.144 \times\left[\mathrm{NO}_{3}{ }^{-}\right]_{\mathrm{eff}}$ $-0.143 \times\left[\mathrm{NH}_{4}{ }^{+}\right]_{\text {Consmp }}+0.152 \times\left[\mathrm{N}_{2}\right](4)$

PCA2 $=-0.134 \times[\mathrm{HS}]_{\mathrm{eff}}+0.808 \times\left[\mathrm{SO}_{4}{ }^{2-}\right]_{\text {eff }}-0.204 \times\left[\mathrm{S}_{2} \mathrm{O}_{3}{ }^{2-}\right]_{\text {eff }}+0.029 \times\left[\mathrm{S}_{0}\right]-0.195 \times\left[\mathrm{NO}_{2}{ }^{-}\right]_{\text {eff }}-0.205 \times\left[\mathrm{NO}_{3}{ }^{-}\right]_{\text {eff }}$ $+0.036 \times\left[\mathrm{NH}_{4}^{+}\right]_{\text {Consmp }}+0.148 \times\left[\mathrm{N}_{2}\right](5)$

Hence, the strategy of regulating the influent $\mathrm{pH}$ was applied during Stage III. The influent $\mathrm{pH}$ was decreased to $6.70 \pm 0.10$ by keeping the influent sulfide concentration at $300 \mathrm{mg} \mathrm{S} / \mathrm{L}$ as in Stage II. It only took 4 days to recover the process performance. On the 4 th day of Stage III, sulfide and nitrate removal percentages were higher than $99.90 \%$ and $90.30 \%$, respectively; furthermore, sulfide and nitrate removal percentages were even higher than $300 \mathrm{mg} \mathrm{S} / \mathrm{L}$ in Stage I, without any detection of the effluent sulfide and nitrite. With the influent sulfide concentration going up to $360 \mathrm{mg} \mathrm{S} / \mathrm{L}$, the bioreactor still showed a good performance, which sulfide and nitrite removal percentages were $99.76 \pm 0.27 \%$ and $100 \%$, respectively. The results provided a strong evidence for the validity of strategy of influent $\mathrm{pH}$ regulation.

\subsection{Comparison of both strategies}

As shown in Table 2, there were significant differences in the removal performance (effluent sulfide and nitrite), main sulfur-containing products (elemental sulfur and Eff. sulfate) and main nitrogen-containing products (nitrogen gas) between $300 \mathrm{mg} \mathrm{S/L}$ in Stage I and that in Stage II, which suggested that 
reduction in the concentration did not recover the process on short-term basis. No significant differences observed on removal performance when the influent $\mathrm{pH}$ was regulated at $6.70 \pm 0.10$, and main products were intermediate nature of $300 \mathrm{mg} \mathrm{S} / \mathrm{L}$ in Stage I and those in Stage III; however, significantly different products were found between $360 \mathrm{mg} \mathrm{S} / \mathrm{L}$ in Stage I and those in Stage III. The results proved that regulating the influent $\mathrm{pH}$ effectively succeeded to recover the process on a short-term basis (4 days).

Table 2

Comparison of removal performance in different stages

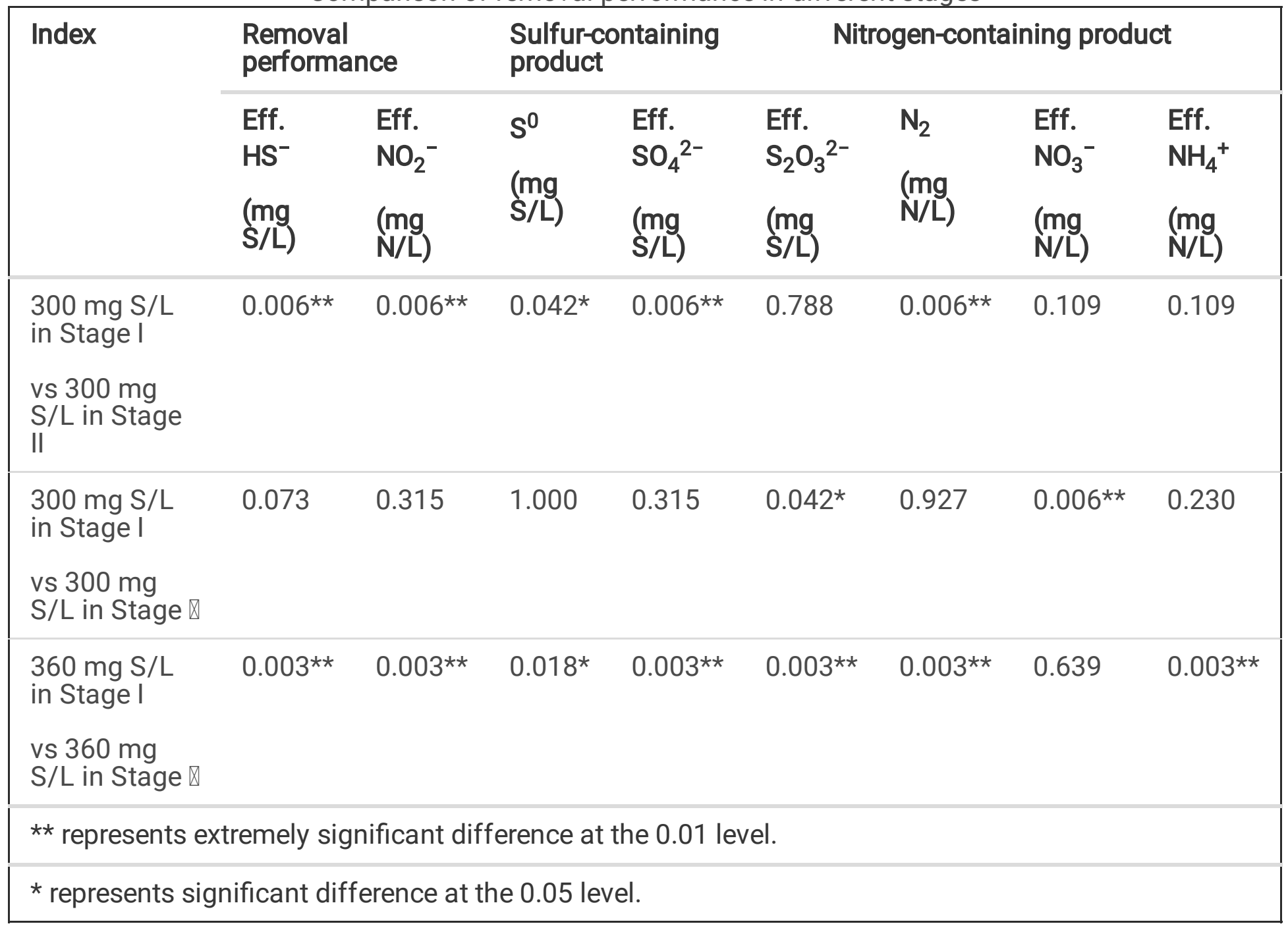

It is worth noting that the variations of minor products (thiosulfate and nitrate) and consumed ammonium were a little different from those of removal percentage and main products, which inferred that regulating the influent $\mathrm{pH}$ would cause a slight impact on product types.

\section{Conclusions}

The two strategies of reducing influent substrate concentration and regulating influent $\mathrm{pH}$ were used to restore the process performance of simultaneous sulfide and nitrite removal after inhibition caused by 
high substrate concentration. For a gradual increase in the influent sulfide concentration from $60 \mathrm{mg} \mathrm{S} / \mathrm{L}$ to $300 \mathrm{mg} \mathrm{S} / \mathrm{L}$, the sulfide and nitrite removal percentages were $92.65 \pm 5.94 \%$ and $99.91 \pm 0.30 \%$, with influent $\mathrm{pH}$ controlled at $7.0 \pm 0.1$. Upon increase in the influent sulfide concentration to $360 \mathrm{mg} \mathrm{S} / \mathrm{L}$, there was a sudden reduction of sulfide and nitrite removal performance, which dropped to $74.19 \%$ and $14.33 \%$, respectively. Reducing the influent substrate concentration to $300 \mathrm{mg} \mathrm{S} / \mathrm{L}$, sulfide removal percentage quickly returned to $91.21 \pm 1.78 \%$ in 4 days' operation; however, nitrite removal percentage still showed a declining tendency, descending from 47.16-18.52\%. Upon regulating the influent $\mathrm{pH}$ around $6.70 \pm 0.10$, the performance recovered in 4 days at $300 \mathrm{mg} \mathrm{S} / \mathrm{L}$. Furthermore, the sulfide and nitrite removal percentages were $99.76 \pm 0.27 \%$ and $100 \%$, respectively, with influent sulfide concentration going up to $360 \mathrm{mg} \mathrm{S} / \mathrm{L}$. Regulating the influent $\mathrm{pH}$ for the rapid performance recovery of was significant based on multiple comparisons $(\mathrm{p}<0.05)$. The strategy of regulating influent $\mathrm{pH}$ for the process performance recovery in a short term (4 days) may be greatly convenient for subsequent research.

\section{Declarations}

\section{Ethics approval}

Not applicable.

\section{Consent to participate}

Not applicable.

\section{Consent for publication}

Not applicable.

\section{Authors' contributions}

$\mathrm{KW}$ performed the experiment and wrote the initial draft. MQ was a major contributor in editing the manuscript. BC participated in the experiment. SL contributed to the conception of the study. YW and ZZ helped perform the analysis with constructive discussions. JC provided financial support for the experiment, and contributed significantly to analysis and manuscript preparation. All authors read and approved the final manuscript.

\section{Funding}

This work was supported by National Natural Science Foundation of China (No.51808494), Zhejiang Provincial Public Welfare Technology Applied Research Projects (No. LGF19E080003), General Scientific Research Projects of Zhejiang Provincial Department of Education (Y202045230) and Zhejiang Gongshang University Graduate Research and Innovation Fund Project (19020160038).

\section{Availability of data and materials}


The datasets used and/or analyzed during the current study are available from the corresponding author on reasonable request.

\section{Competing interests}

The authors declare that they have no conflict of interest.

\section{References}

1. An S, Tang K, Nemati M (2010) Simultaneous biodesulphurization and denitrification using an oil reservoir microbial culture: Effects of sulphide loading rate and sulphide to nitrate loading ratio. Water Res 44:1531-1541. doi:10.1016/j.watres.2009.10.037

2. APHA, AWWA, WPCF (1998) Standard methods for the examination of water and wastewater. 20th edn. American Public Health Association, Washington, DC

3. Cardoso RB, Sierra-Alvarez R, Rowlette P, Flores ER, Gomez J, Field JA (2006) Sulfide oxidation under chemolithoautotrophic denitrifying conditions. Biotechnol Bioeng 95:1148-1157. doi:10.1002/bit.21084

4. Chung J, Amin K, Kim S, Yoon S, Kwon K, Bae W (2014) Autotrophic denitrification of nitrate and nitrite using thiosulfate as an electron donor. Water Res 58:169-178.

doi:10.1016/j.watres.2014.03.071

5. Deng Y-F, Wu D, Huang H, Cui Y-X, van Loosdrecht MCM, Chen G-H (2021) Exploration and verification of the feasibility of sulfide-driven partial denitrification coupled with anammox for wastewater treatment. Water Res 193:116905. doi:https://doi.org/10.1016/j.watres.2021.116905

6. Fajardo C, Mora M, Fernandez I, Mosquera-Corral A, Campos JL, Mendez R (2014) Cross effect of temperature, $\mathrm{pH}$ and free ammonia on autotrophic denitrification process with sulphide as electron donor. Chemosphere 97:10-15. doi:10.1016/j.chemosphere.2013.10.028

7. Karanasios KA, Vasiliadou IA, Pavlou S, Vayenas DV (2010) Hydrogenotrophic denitrification of potable water: a review. J Hazard Mater 180:20-37. doi:10.1016/j.jhazmat.2010.04.090

8. Mahmood Q, Zheng P, Cai J, Wu D, Hu B, Li J (2007) Anoxic sulfide biooxidation using nitrite as electron acceptor. J Hazard Mater 147:249-256. doi:10.1016/j.jhazmat.2007.01.002

9. Show KY, Lee DJ, Pan X (2013) Simultaneous biological removal of nitrogen-sulfur-carbon: recent advances and challenges. Biotechnol Adv 31:409-420. doi:10.1016/j.biotechadv.2012.12.006

10. Tang C, Zheng P, Chen X (2010) Substrate Inhibition and Recovery Strategies for Anammox Process. Journal of Basic Science and Engineering 18:561-570.

11. Xu J, Ding K, Yang C, Huang T (2019) Regulation of influent sulfide concentration on anaerobic denitrifying sulfide removal. Environ Technol 40:1392-1400. doi:10.1080/09593330.2017.1422552

12. Yuan Y, Li X, Li BL (2020) Autotrophic nitrogen removal characteristics of $P N$-anammox process enhanced by sulfur autotrophic denitrification under mainstream conditions. Bioresour Technol 316:123926. doi:10.1016/j.biortech.2020.123926 
13. Zhang RC et al. (2019) Bioreactor performance and microbial community analysis of autotrophic denitrification under micro-aerobic condition. Sci Total Environ 647:914-922. doi:10.1016/j.scitotenv.2018.07.389

14. Zheng $X$ et al. (2013) The long-term effect of nitrite on the granule-based enhanced biological phosphorus removal system and the reversibility. Bioresour Technol 132:333-341. doi:https://doi.org/10.1016/j.biortech.2013.01.042

15. Zhou Y, Pijuan M, Yuan Z (2007) Free nitrous acid inhibition on anoxic phosphorus uptake and denitrification by poly-phosphate accumulating organisms. Biotechnol Bioeng 98:903-912. doi:https://doi.org/10.1002/bit.21458

\section{Figures}

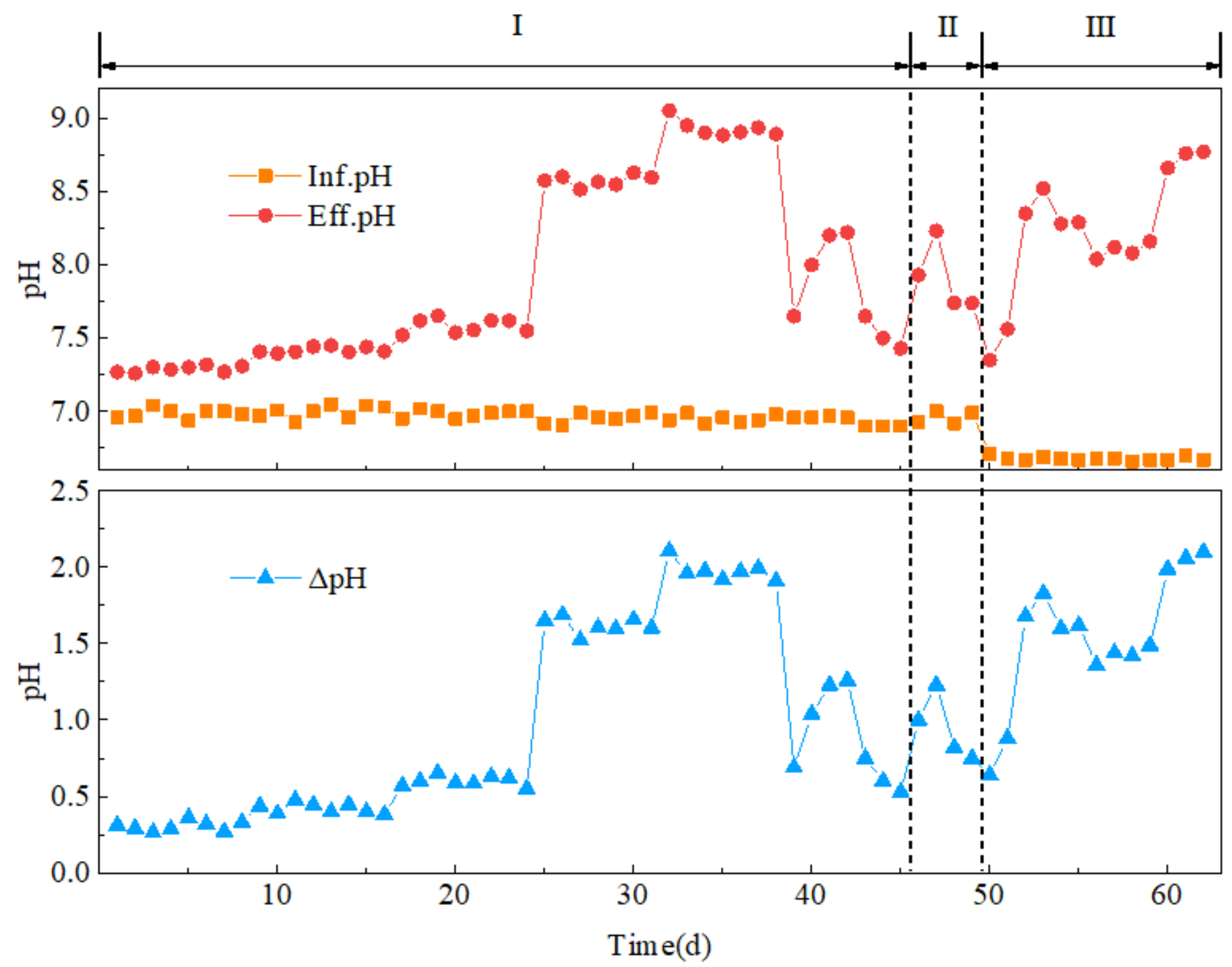

\section{Figure 1}

Variations of $\mathrm{pH}$ in the simultaneous sulfide and nitrite removal process $(\Delta \mathrm{pH}=\mathrm{pHinf}-\mathrm{pHeff})$ 


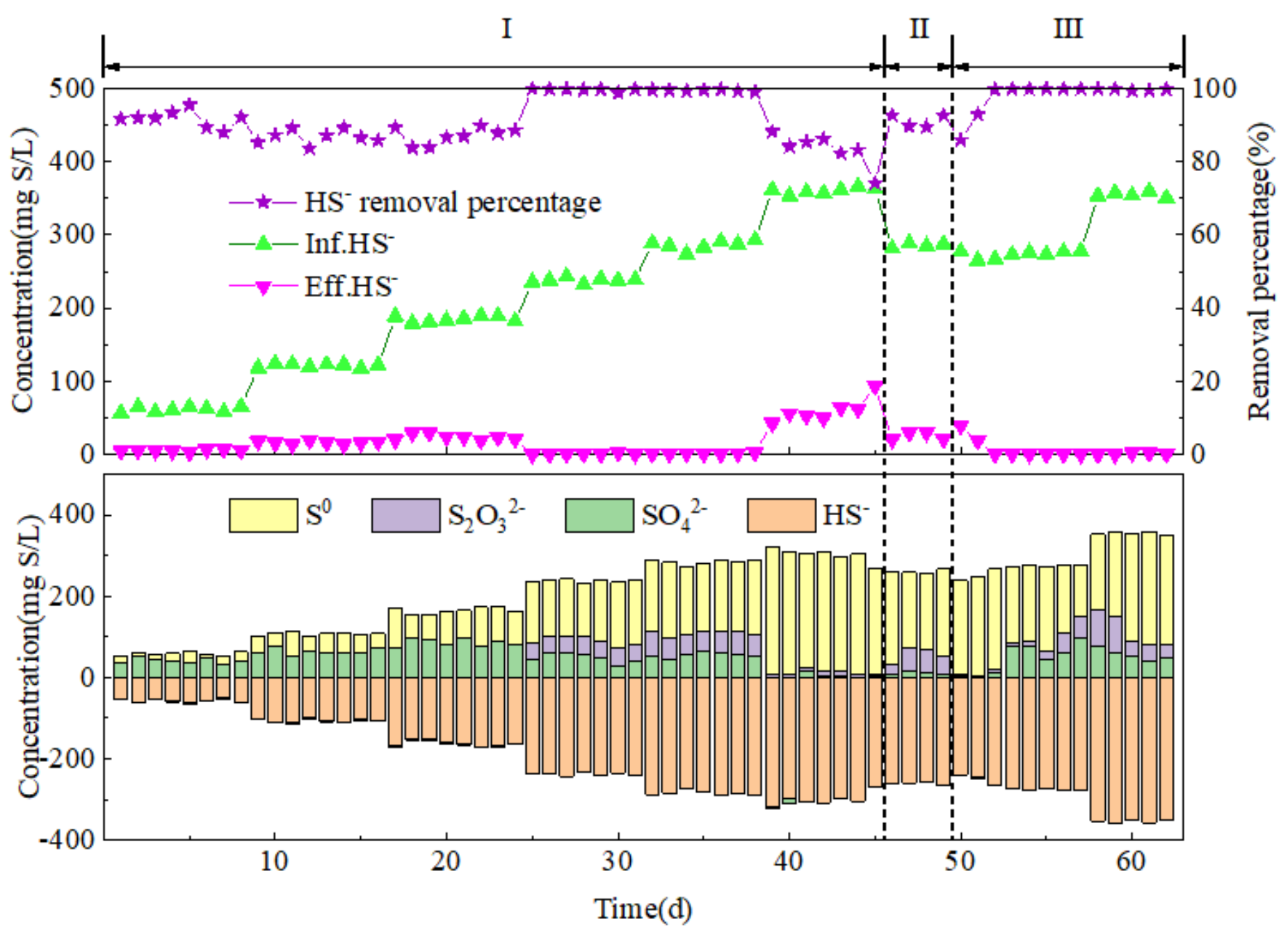

Figure 2

Sulfide removal performance in the simultaneous sulfide and nitrite removal process 


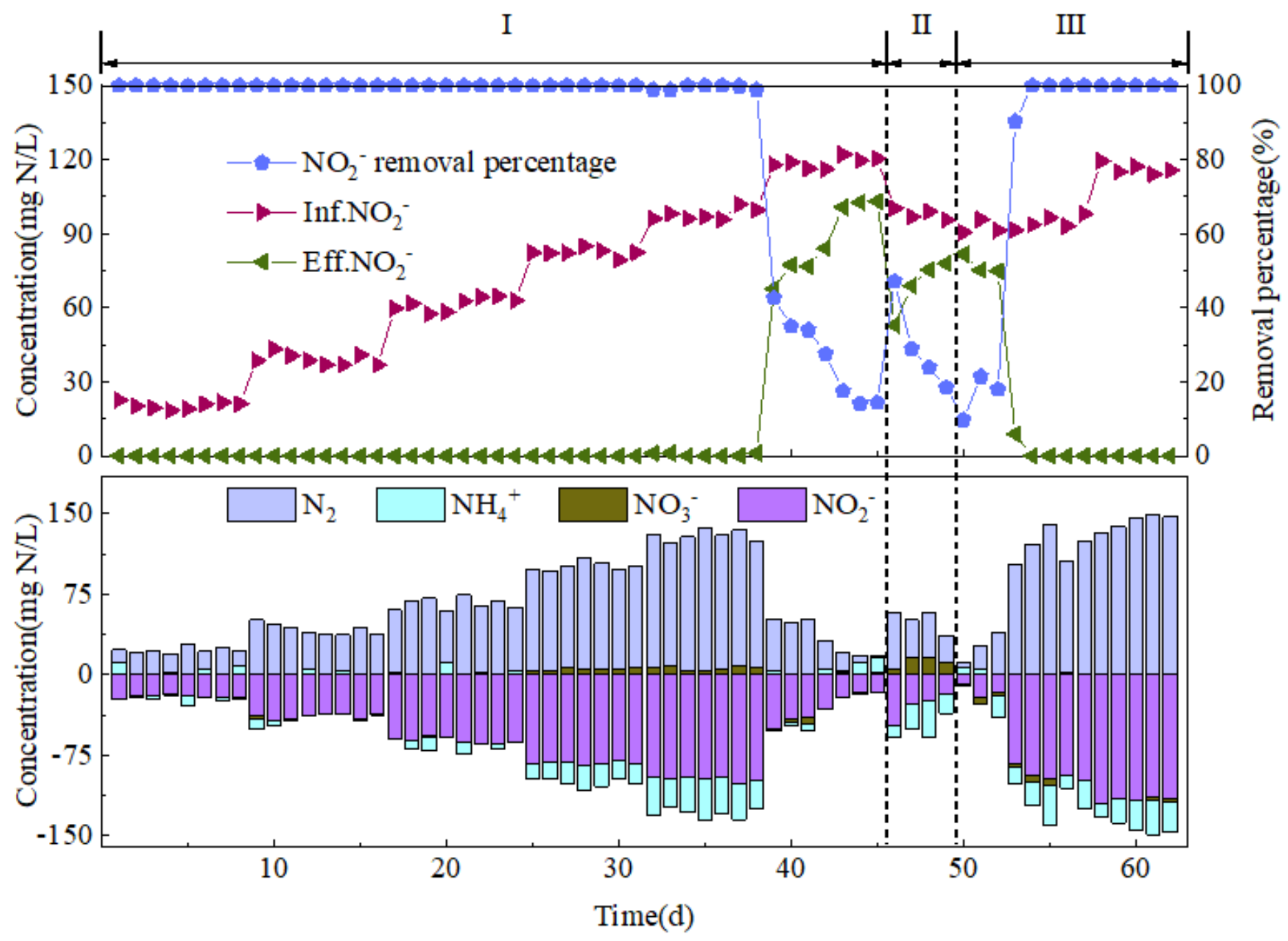

Figure 3

Nitrite removal performance in the simultaneous sulfide and nitrite removal process

\section{Supplementary Files}

This is a list of supplementary files associated with this preprint. Click to download.

- SupplementalMaterial.docx 